\title{
Relationship between cropping frequency, root rot and yield of silage maize on sandy soils
}

\author{
K. Scholte \\ Department of Field Crops and Grassland Science, Wageningen Agricultural Uni- \\ versity, Haarweg 333, NL 6709 RZ Wageningen, Netherlands
}

Received 2 February 1987; accepted 10 May 1987

Key words: continuous cropping, rotation, slurry, nematicide, Pythium, Fusarium, Rhizoctonia solani, Zea mays, root rot, cropping frequency

\begin{abstract}
Continuous cropping and a prolonged 1:2 rotation of silage maize resulted in yields $10-20 \%$ lower than those of maize in broad rotations. Neither annual applications of 100 tonnes of cattle slurry per hectare, nor applications of nematicides, reduced the adverse effects of continuous cropping. Continuous cropping stimulated root rot. A close negative relation was found between cropping frequency, incidence of root rot and yield of maize. Root rot seemed to be caused mainly by Pythium spp., and indications were found that it occurred more seriously in years in which the first half of the growing season was wetter than normal.
\end{abstract}

\section{Introduction}

The area under silage maize in the Netherlands has increased from 6000 ha in 1970 to nearly 200000 ha in 1986 . The crop is mainly grown on cattle farms and therefore is often grown on one and the same field. Schröder (1986) showed that, on sandy soils, about $60 \%$ of the total area under maize is grown continuously on the same field. It is known from other crops that narrow crop rotation and especially continuous cropping leads to lower yields owing to an increased incidence of soil pathogens. This paper presents results of a long-term comprehensive study of the effects of crop rotation on the yield of silage maize and on the development of root diseases.

\section{Materials and methods}

\section{Experiment 1}

This experiment was started in 1979 near Wageningen on a light, sandy soil contain- 


\section{K. SCHOLTE}

ing $2.6 \%$ organic matter and having a $\mathrm{pH}-\mathrm{KCl}$ of 5.2. Prior to the experiment, winter rye (1978), potatoes (1977), winter rye (1976) and maize (1975) had been grown on the trial field.

For convenience, continuous cropping will be designated as one of three rotations;

$\mathrm{M}=$ continuous cropping of maize,

$\mathrm{PM} \quad=$ potato-maize,

SBBPM = sugar-beet-barley-barley-potato-maize.

The rotations on untreated plots were compared with rotations on plots treated annually with a granular nematicide even when a crop other than maize was grown. Nematicides were applied to study the effects of nematodes on yield production. The nematicide was always broadcast one day before sowing and then incorporated into the soil with a spring-tine cultivator. Oxamyl (Vydate $10 \mathrm{G}, 50 \mathrm{~kg} \mathrm{ha}^{-1}$ ) was applied from 1979 to 1984 , and aldicarb (Temik $10 \mathrm{G}, 30 \mathrm{~kg} \mathrm{ha}^{-1}$ ) in 1985 and 1986.

The experiment was laid out in a completely randomized block design with four replications; every crop in a rotation was grown in each year. Within each block, continuous cropping of maize $(\mathrm{M})$ occurred in duplicate. The plots were $12 \times 6=72$ $\mathrm{m}^{2}$, of which $10 \times 3=30 \mathrm{~m}^{2}$ were harvested. The blocks were separated by strips 12 $\mathrm{m}$ wide, on which barley was grown each year. The strips served as headland for mechanized cultivation.

Every year the fields were worked with a cultivator in autumn, after the crops had been harvested. They were ploughed early in March the following year. Averaged over the experimental period, yearly rates of fertilizers on maize fields were $234 \mathrm{~kg} \mathrm{~N}, 196 \mathrm{~kg} \mathrm{P}_{2} \mathrm{O}_{5}, 242 \mathrm{~kg} \mathrm{~K} \mathrm{~K}_{2} \mathrm{O}, 165 \mathrm{~kg} \mathrm{MgO}, 0.6 \mathrm{~kg} \mathrm{~B}, 0.6 \mathrm{~kg} \mathrm{Cu}$ and $650 \mathrm{~kg}$ $\mathrm{CaO}$ per hectare.

The maize cultivar Dorina was sown in rows $75 \mathrm{~cm}$ apart in all years between 22 April and 2 May. The final harvests depended on kernel ripeness and took place from the end of September until mid-October.

In all years weeds were adequately controlled with chemicals. In dry periods the experimental field was irrigated with sprinklers.

\section{Experiment 2}

This experiment was also started in 1979 near Wageningen on a sandy soil containing 3.3\% organic matter and having a $\mathrm{pH}-\mathrm{KCl}$ of 5.3. Maize had been grown on the trial field in 1978, and for at least the preceding 20 years the field had been under permanent grassland. Two rotations were compared:

$\mathrm{M}=$ continuous maize cropping,

SBPM = sugar-beet-barley-potato-maize.

These two rotations were compared on plots without application of slurry and on plots that were manured annually with 100 tonnes of cattle slurry per hectare even when a crop other than maize was grown. The slurry treatment was included in the experiment because in the Netherlands farmers apply slurry to their maize fields annually, and this might have an effect on the incidence of root diseases.

The experiment was laid out as a split-plot design with slurry application in the 
main plots and with three replications. Every crop in a rotation was grown each year. Within each block, continuous cropping of maize (M) occurred in duplicate. The plots were $12 \times 6=72 \mathrm{~m}^{2}$, of which $10 \times 3=30 \mathrm{~m}^{2}$ were harvested. The blocks and main plots were separated by strips $12 \mathrm{~m}$ wide, on which barley was grown each year. The strips served as headland for mechanized cultivation and as a safety zone for the application of slurry.

Every year the fields were worked with a cultivator in autumn, after the crops had been harvested. After the application of slurry in March of the following year, the fields were ploughed. Averaged over the experimental period, dry matter content of the slurry was $8.1 \%$. On the basis of chemical analysis it was calculated that per year $280 \mathrm{~kg} \mathrm{~N}, 180 \mathrm{~kg} \mathrm{P}_{2} \mathrm{O}_{5}, 380 \mathrm{~kg} \mathrm{~K}_{2} \mathrm{O}, 80 \mathrm{~kg} \mathrm{MgO}$ and $170 \mathrm{~kg} \mathrm{CaO}$ were applied per hectare. Of the $280 \mathrm{~kg} \mathrm{~N}$ applied per hectare, it may be expected that $40 \%$ was available for plant nutrition in the year of application (Kolenbrander, 1981).

On an average, yearly rates of inorganic fertilizers for maize on the no-slurry fields were $228 \mathrm{~kg} \mathrm{~N}, 161 \mathrm{~kg} \mathrm{P}_{2} \mathrm{O}_{5}, 192 \mathrm{~kg} \mathrm{~K}_{2} \mathrm{O}, 61 \mathrm{~kg} \mathrm{MgO}$ and $337 \mathrm{~kg} \mathrm{CaO}$ per ha; on the slurry-treated fields the rates were $101 \mathrm{~kg} \mathrm{~N}, 75 \mathrm{~kg} \mathrm{P}_{2} \mathrm{O}_{5}, 0 \mathrm{~kg} \mathrm{~K}_{2} \mathrm{O}, 61 \mathrm{~kg}$ $\mathrm{MgO}$ and $337 \mathrm{~kg} \mathrm{CaO}$ per hectare.

Cultivar, row spacing, weed control and irrigation were the same as in Experiment 1 , and sowing dates and final harvest dates were very similar.

\section{Experiment 3}

In March 1986, soil samples were taken from field of Experiments 1 and 2, viz from $M$ plots that had been continuously cropped with maize for 7 years, and from SBBPM plots (Exp. 1) and SBPM plots (Exp. 2), where maize should be sown in that year. The soil was used for a pot experiment. Therefore each lot of soil was sieved and thoroughly mixed. The five following soil treatments were applied:

$\mathrm{C}=$ control (no treatment);

$\mathrm{P}=$ pencycuron (Monceren-25\% a.i.), fungicide effective against Rhizoctonia solani;

B = benomyl (Benlate-50 \% a.i.), fungicide effective against Fusarium spp.;

$\mathrm{M}=$ metalaxyl (Ridomil WP-25\% a.i.), fungicide effective against Pythium spp.; $\mathrm{S}=$ sterilization by gamma irradiation.

One day before sowing of maize, pencycuron, benomyl and metalaxyl were thoroughly mixed with the soil, at rates of 40,100 and $10 \mathrm{mg} / \mathrm{l}$ soil, respectively. Pencycuron and benomyl were applied again 66 days after sowing and metalaxyl 46, 66 and 89 days after sowing. At these times pencycuron, benomyl and metalaxyl were applied by drenching the soil with fungicide solution at rates of 10,10 and $5 \mathrm{mg} / \mathrm{l}$ soil, respectively. One week before sowing, the soil was sterilized by gamma irradiation with $25 \mathrm{kGy}$.

Black plastic pots $(5.81)$ were filled with treated soil and placed in white enamel pots. They were ranged under a transparent plastic roof for 53 days in a completely randomized block design with 8 replications and were then put outdoors for the summer months. 
The cultivar used was Dorina. On 4 April 1986, 7 seeds were sown per pot and one week after emergence thinned to 3 plants per pot. From the date of emergence the following total amounts of nutrients were applied per pot, apportioned over nine applications at 10-day intervals: $5544 \mathrm{mg} \mathrm{N}, 1395 \mathrm{mg} \mathrm{P}, 8073 \mathrm{mg} \mathrm{K}, 648 \mathrm{mg} \mathrm{Mg}$ and $18 \mathrm{ml}$ of a trace element solution containing $20 \mathrm{~g} \mathrm{MnSO}_{4} \cdot 1 \mathrm{H}_{2} \mathrm{O}, 30 \mathrm{~g} \mathrm{H}_{3} \mathrm{BO}_{3}, 5 \mathrm{~g}$ $\mathrm{ZnSO}_{4} \cdot 7 \mathrm{H}_{2} \mathrm{O}$ and $1 \mathrm{~g} \mathrm{Na}_{2} \mathrm{MoO}_{4} \cdot 2 \mathrm{H}_{2} \mathrm{O}$ per litre water. The total amounts of the main elements were based on expected dry matter yields.

\section{Survey}

In 1986 a survey was carried out on 91 farmers' fields to study the occurrence of root rot. The fields were selected on the basis of three cropping frequencies for maize, viz $100 \%$ (for at least five years), $33 \%$ and $16 \%$ (or lower). In the latter case, permanent grassland was mostly (about $80 \%$ ) the preceding crop for maize.

Per field 15 root systems were dug out, rinsed in water and scored for root health in the same way as was done for Experiments 1 and 2.

\section{Analysis}

In Experiments 1 and 2, at the end of the growing season, total fresh yield was determined annually be mechanically harvesting $30 \mathrm{~m}^{2}$ per plot. Dry matter content of the fresh mass was determined in four samples per plot that were dried in forcedventilated ovens at $105^{\circ} \mathrm{C}$ for 16 hours. In 1985, in both experiments, the increase in dry matter yield was monitored in three harvests of 24 plants taken at random per plot on 17 June, 23 July and 28 August. Furthermore, the number of plants per $\mathrm{m}^{2}$ was counted and plant height and root health were ascertained from the 24 harvested plants. Root health was expressed in a score: $10=$ white healthy roots, $8=$ slight attack of root rot, $6=$ moderate attack of root rot, $4=$ severe attack of root rot, $2=$ very severe attack of root rot and $0=$ roots completely rotten. In 1986, number of plants per $\mathrm{m}^{2}$, number of barren plants per $\mathrm{m}^{2}$ and plant height were recorded.

In Experiment 3, the final harvest took place on 4 August 1986, with 8 replications per treatment. Total dry matter yield and root health were assessed.

\section{Results}

\section{Experiments 1 and 2}

Total dry matter yield of silage maize is given in Table 1 . In the first five years, the yield obtained with continuous cropping of maize was less than $10 \%$ below that of maize grown in broad rotations, but from 1984 the disparity increased and reached levels between 10 and $20 \%$.

In Experiment 1, the 1:2 PM rotation showed only a slight yield reduction in the cycles 2 (1981 and 1982) and 3 (1983 and 1984). However, in cycle 4 (1985 and 1986 ) yield depression was comparable with that under continuous cropping. 
Table 1. Total dry matter yield of silage maize in different crop rotations ${ }^{1}$.

\begin{tabular}{|c|c|c|c|c|c|c|c|}
\hline \multirow[t]{3}{*}{ Year } & \multicolumn{4}{|c|}{ Experiment 1} & \multicolumn{3}{|c|}{ Experiment 2} \\
\hline & \multicolumn{2}{|c|}{$\overline{\text { SBBPM }}$} & \multirow{2}{*}{$\frac{\mathrm{PM}^{2}}{\text { rel. }}$} & \multirow{2}{*}{$\frac{\mathrm{M}}{\text { rel. }}$} & \multicolumn{2}{|c|}{ SBPM } & \multirow{2}{*}{$\frac{\mathrm{M}}{\text { rel. }}$} \\
\hline & t/ha & rel. & & & t/ha & rel. & \\
\hline 1980 & 12.0 & $100 a^{3}$ & $100 \mathrm{a}$ & $95 \mathrm{a}$ & 13.8 & $100 \mathrm{a}$ & $100 \mathrm{a}$ \\
\hline 1981 & 14.7 & $100 a$ & x $99 a$ & $95 \mathrm{a}$ & 15.4 & $100 \mathrm{a}$ & $94 \mathrm{a}$ \\
\hline 1982 & 16.3 & $100 \mathrm{a}$ & x $95 a b$ & $93 \mathrm{~b}$ & 16.4 & $100 \mathrm{a}$ & $98 \mathrm{a}$ \\
\hline 1983 & 14.9 & $100 \mathrm{a}$ & y $98 \mathrm{ab}$ & $92 \mathrm{~b}$ & 17.0 & $100 a$ & $91 \mathrm{~b}$ \\
\hline 1984 & 10.2 & $100 \mathrm{a}$ & y $94 \mathrm{ab}$ & $85 \mathrm{~b}$ & 11.6 & $100 \mathrm{a}$ & $82 \mathrm{~b}$ \\
\hline 1985 & 15.5 & $100 \mathrm{a}$ & $\mathrm{z} 85 \mathrm{~b}$ & $81 \mathrm{~b}$ & 13.3 & $100 \mathrm{a}$ & $84 \mathrm{~b}$ \\
\hline 1986 & 19.8 & $100 \mathrm{a}$ & $\mathrm{z} 85 \mathrm{~b}$ & $87 \mathrm{~b}$ & 17.5 & $100 \mathrm{a}$ & $89 \mathrm{~b}$ \\
\hline
\end{tabular}

1 SBBPM = sugar-beet-barley-barley-potato-maize

SBPM = sugar-beet-barley-potato-maize

$\mathrm{PM} \quad=$ potato-maize

$\mathrm{M} \quad=$ continuous cropping of maize.

${ }^{2} \mathrm{x}, \mathrm{y}$ and $\mathrm{z}$ are years of the second, third and fourth cycle, respectively.

${ }^{3}$ Dissimilar letters indicate significant differences between rotations within a year at $P<0.05$ (according to the multiple range test of Student/Newman/Keuls).

Table 2. Effect of nematicides on dry matter yields of maize in three rotations, expressed as a relative value between the treated rotation and the corresponding untreated rotation. Experiment 1.

\begin{tabular}{llll}
\hline Year & \multicolumn{2}{c}{ Rotation $^{1}$} & \\
\cline { 2 - 4 } & SBBPM & PM & M \\
& 100 & 108 & 104 \\
1979 & 103 & 101 & 102 \\
1980 & 106 & 95 & 97 \\
1981 & 92 & 102 & 98 \\
1982 & 106 & 100 & 103 \\
1983 & 98 & 96 & 106 \\
1984 & 99 & 97 & 106 \\
1985 & 99 & 96 & 102 \\
1986 & & & \\
& 100 n.s. & 99 n.s. & 102 n.s. \\
\hline Mean & &
\end{tabular}

${ }^{1}$ Symbols as in Table 1.

${ }^{2}$ n.s. $=$ effect of the nematicide application is not significant within a rotation.

In Experiment 1, Pratylenchus spp. and Tylenchorynchus dubius were the most common nematodes, and applications of granular nematicides greatly reduced their numbers (Scholte \& s'Jacob, 1983). However, Table 2 shows that disinfecting the soil with granular nematicides did not significantly boost the dry matter yield in any of the three rotations. From Table 3 it can be seen that the yearly application of 100 $t$ of cattle slurry per hectare did not lessen the yield reduction accompanying continuous cropping. 
Table 3. Relative yield depression accompanying continuous cropping of maize, on fields with or without a yearly application of cattle slurry of $100 \mathrm{tha}^{-1}$, compared with the rotation SBPM. Experiment 2 .

\begin{tabular}{lll}
\hline Year & No slurry & With slurry \\
1980 & 101 & 98 \\
1981 & 93 & 95 \\
1982 & 98 & 97 \\
1983 & 89 & 95 \\
1984 & 83 & 82 \\
1985 & 84 & 84 \\
1986 & 88 & 90 \\
Mean $^{1}$ & 91 a & 92 a \\
\hline
\end{tabular}

${ }^{1}$ Similar letters indicate that the yearly application of $100 \mathrm{t}$ of cattle slurry did not affect significantly the level of yield depression owing to continuous cropping of maize.

Fig. 1 shows the course of dry matter production during the growing season in 1985. In both experiments, yield reductions that occurred with continuous cropping started in mid-June and from then onwards increased gradually. In Experiment 1, the curve for PM only deviated from that of continuous cropping at the end of the growing season.

In certain years, not only dry matter production was assessed, but other crop parameters were also recorded. These observations are summarized in Table 4. From this table it can be seen that in the maize crops the number of plants per $\mathrm{m}^{2}$ and the dry matter content at final harvest did not differ significantly between the various rotations. The average weight per plant and the plant height were much lower with continuous cropping than in broad rotations. In 1986, in farmers' fields it was ob-
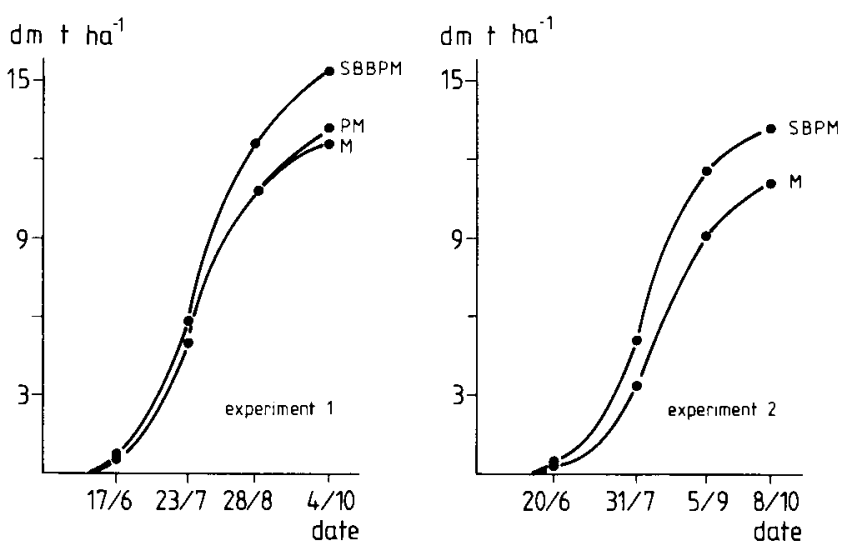

Fig. 1. Dry matter yield of maize in various rotations (symbols as in Table 1) on different dates in 1985. Experiments 1 and 2 . 
Table 4. Effect of different rotations on some crop parameters of maize. Experiments 1 and 2.

\begin{tabular}{|c|c|c|c|c|c|}
\hline \multirow[t]{2}{*}{ Crop parameter } & \multicolumn{3}{|c|}{ Experiment 1} & \multicolumn{2}{|c|}{ Experiment 2} \\
\hline & SBBPM & PM & $M$ & SBPM & M \\
\hline Number of plants $/ \mathrm{m}^{2 *}$ & $10.3 \mathrm{a}^{1}$ & $10.3 \mathrm{a}$ & $10.3 \mathrm{a}$ & $10.0 \mathrm{a}$ & $10.0 \mathrm{a}$ \\
\hline$\%$ DM in fresh mass** & $32.3 \mathrm{a}$ & $32.9 \mathrm{a}$ & $32.2 \mathrm{a}$ & $30.8 \mathrm{a}$ & $30.9 \mathrm{a}$ \\
\hline g DM per plant* & $170 \mathrm{a}$ & $147 \mathrm{~b}$ & $144 \mathrm{~b}$ & 151 a & $132 \mathrm{~b}$ \\
\hline Plant height in $\mathrm{cm}^{*}$ & $260 a$ & $249 \mathrm{~b}$ & $249 \mathrm{~b}$ & $254 \mathrm{a}$ & $237 \mathrm{~b}$ \\
\hline$\psi_{c}$ of barren plants ${ }^{* * *}$ & $2.3 \mathrm{a}$ & $7.4 \mathrm{~b}$ & $8.0 \mathrm{~b}$ & $4.6 \mathrm{a}$ & $7.8 \mathrm{~b}$ \\
\hline
\end{tabular}

* Averaged over 1985 and 1986.

** Averaged over 1983 to 1986 .

*** 1986 .

1 See footnote 3 in Table 1.

served that not all plants always bore a cob. Countings in Experiments 1 and 2 showed that the number of barren plants was considerably higher in continuous cropping than in broad rotations.

Fig. 2 shows that in 1985 , in both experiments, root health decreased much faster with continuous cropping (M) and also with the 1:2 rotation (PM) than in the broad rotations (SBBPM and SBPM).

In 1985, at final harvest in Experiment 1, potassium content of the soil was high and no differences were found between rotations. In Experiment 2, potassium content was higher in $\mathrm{M}$ fields than in SBPM fields, both in no-slurry fields and in slurry-treated fields. In both experiments, phosphorus content of the soil was high and no clear differences were found between rotations.
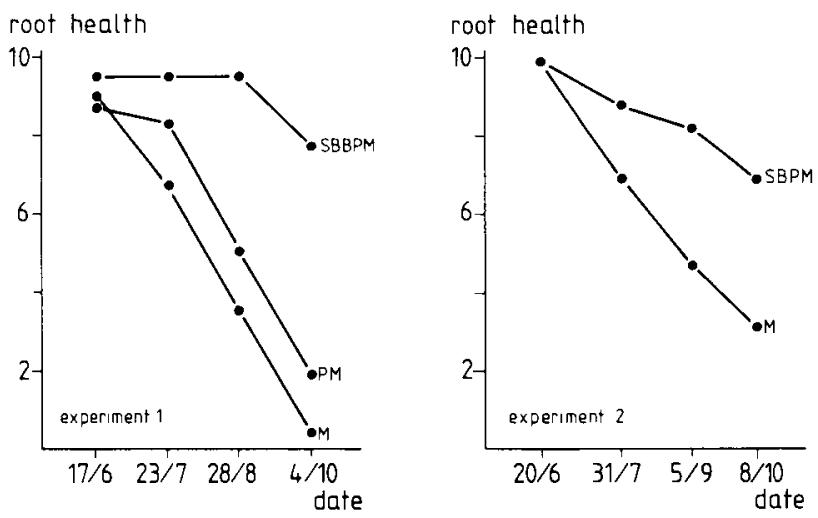

Fig. 2. Score for root health of maize $(10=$ sound white roots, $0=$ completely rotten root system $)$ in various rotations (symbols as in Table 1) on different dates in 1985. Experiments 1 and 2. 


\section{K. SCHOLTE}

\section{Experiment 3}

Table 5 shows that in the untreated soils, yields of continuous cropping (M) were $27 \%$ lower in soil from Experiment 1, and $18 \%$ lower in soil from Experiment 2 than yields of broad rotations. After the soil had been sterilized by gamma irradiation, the negative effect of continuous cropping disappeared completely. Treating the soil with pencycuron did not change the ratios in yield between continuous cropping and the broad rotations. On the other hand, metalaxyl was very effective in eliminating yield depresion: in soil from Experiment 1, yield increased considerably in $\mathrm{M}$, and the maize yield in SBBPM was as high as that obtained on gamma-irradiated soil. In soil from Experiment 2, metalaxyl also had a positive effect on yield in $\mathrm{M}$, but this effect was less pronounced than with soil of Experiment 1. Some phytotoxicity seemed to be present with this fungicide in SBPM. The same can be said of benomyl in soil from Experiment 1: a slightly negative effect was found in SBBPM, but not in M. In soil from Experiment 2, benomyl seemed to be as effective as metalaxyl.

In the untreated soils, root health was much worse in M than in SBBPM or SBPM (Table 5). Pencycuron did not have any positive effect on root health. Benomyl improved root health in $\mathrm{M}$ with soil of Experiment 2, but this was less evident with soil of Experiment 1. Sterilizing the soil by gamma irradiation resulted in the root sys-

Table 5. Effect of different soil treatments on relative dry matter yield of silage maize and on root health at final harvest (score $10=$ sound white roots, $0=$ completely rotten root system). Experiment 3.

Soil origin

Relative dry matter yield

Experiment 1

Experiment 2

Root health

\begin{tabular}{|c|c|c|c|c|c|c|}
\hline Experiment 1 & $\begin{array}{l}\text { SBBPM } \\
\mathrm{M}\end{array}$ & $\begin{array}{l}7.4 \mathrm{c} \\
2.0 \mathrm{a}\end{array}$ & $\begin{array}{l}7.4 \mathrm{c} \\
1.4 \mathrm{a}\end{array}$ & $\begin{array}{l}6.8 \mathrm{c} \\
4.0 \mathrm{~b}\end{array}$ & $\begin{array}{l}9.0 \mathrm{~d} \\
7.0 \mathrm{c}\end{array}$ & $\begin{array}{l}9.6 \mathrm{~d} \\
9.6 \mathrm{~d}\end{array}$ \\
\hline Experiment 2 & $\begin{array}{l}\text { SBPM } \\
\text { M }\end{array}$ & $\begin{array}{l}7.9 \mathrm{c} \\
4.8 \mathrm{a}\end{array}$ & $\begin{array}{l}7.8 \mathrm{c} \\
4.6 \mathrm{a}\end{array}$ & $\begin{array}{l}8.5 c \\
7.9 c\end{array}$ & $\begin{array}{l}8.5 c \\
6.8 b\end{array}$ & $\begin{array}{l}9.6 \mathrm{~d} \\
9.5 \mathrm{~d}\end{array}$ \\
\hline
\end{tabular}

\begin{tabular}{lllll} 
Rotation & \multicolumn{2}{l}{} & & \\
& Soil treatment $^{1}$ & & \\
C & P & B & M & S
\end{tabular}

$\begin{array}{lcclll}\text { SBBPM }^{4} & 100^{2} \mathrm{~cd}^{5} & 100 \mathrm{~cd} & 92 \mathrm{~d} & 116 \mathrm{~b} & 116 \mathrm{~b} \\ \text { M } & 73 \mathrm{e} & 70 \mathrm{e} & 76 \mathrm{e} & 102 \mathrm{c} & 130 \mathrm{a} \\ & & & & & \\ \text { SBPM } & 100^{3} \mathrm{ab} & 100 \mathrm{ab} & 99 \mathrm{ab} & 94 \mathrm{~b} & 109 \mathrm{a} \\ \text { M } & 82 \mathrm{c} & 81 \mathrm{c} & 93 \mathrm{~b} & 91 \mathrm{~b} & 107 \mathrm{a}\end{array}$


tem being very healthy at the end of the growing season. The effects of soil treatments on root health with soil of Experiment 1 are visible in Fig. 3.

Fig. 4 shows a close relationship between root health and dry matter yield. Nearly $90 \%$ of the total variation in dry matter yield can be explained by differences in root health.

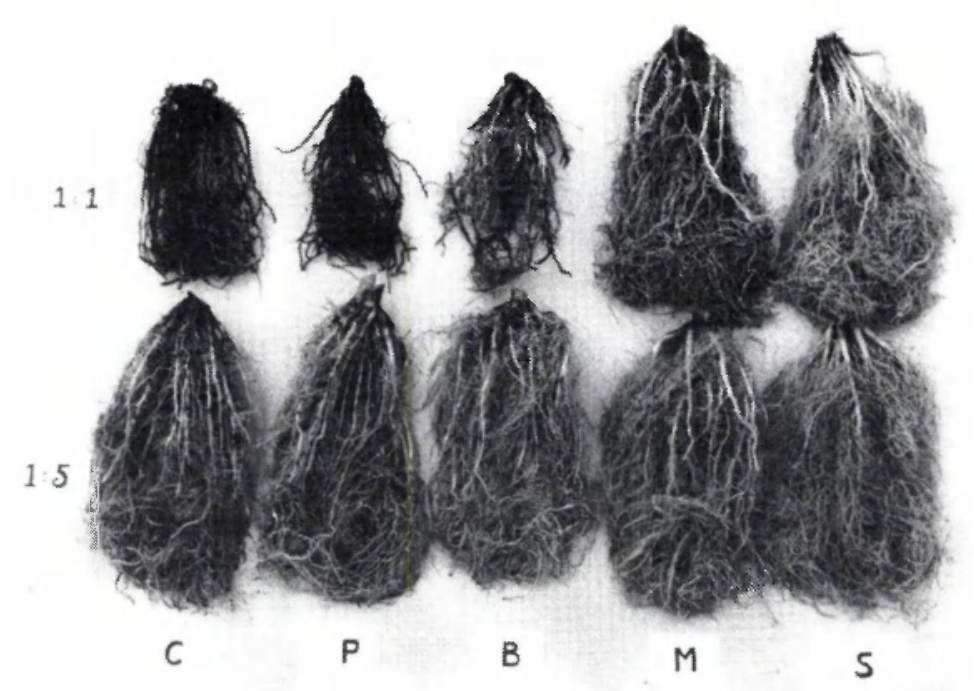

Fig. 3. Root health of maize, according to rotation (1:1 = continuous cropping, $1: 5=$ SBBPM, both soils from Exp. 1) and soil treatment (C, P, B, M, S: see Table 5). Experiment 3.

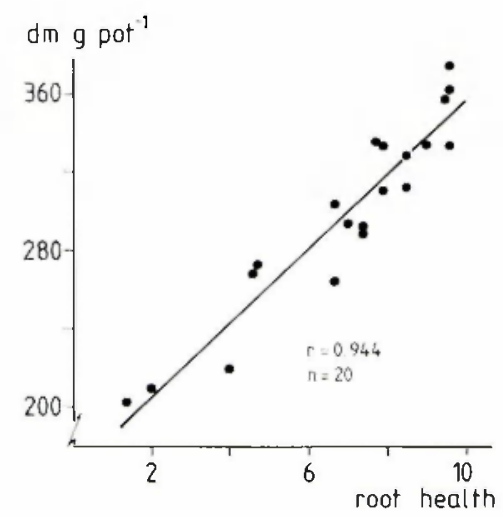

Fig. 4. Relationship between dry matter yield and root health (score: $10=$ sound white roots, $0=$ completely rotten root system). Experiment 3. 
Table 6. Frequency distribution of fields over five classes of root health, and the mean scores for root health in a survey of 91 farmers' fields.

\begin{tabular}{lccc}
\hline Root health class ${ }^{1}$ & \multicolumn{3}{c}{ Cropping frequency of maize } \\
\cline { 2 - 4 } & $<16 \%$ & $33 \%$ & $100 \%$ \\
$0.0-2.0$ & 0 & 0 & 0 \\
$2.1-4.0$ & 0 & 4 & 37 \\
$4.1-6.0$ & 3 & 28 & 49 \\
$6.1-8.0$ & 7 & 36 & 14 \\
$8.1-10.0$ & 90 & 32 & 0 \\
Mean score & \\
1 & $8.9 \mathrm{a}$ & $6.9 \mathrm{~b}$ & $4.5 \mathrm{c}$ \\
2 & \\
10 = sound white roots, $0=$ completely rotten root system. \\
ing to the Studentized range test of Tukey).
\end{tabular}

\section{Survey}

Table 6 shows that on farmers' fields the incidence of root rot was highly determined by the cropping frequency of maize.

\section{Discussion}

Crop rotation experiments 1 and 2 demonstrate that continuous cropping of maize gives lower yields than growing maize in broad rotations. After five years of continuous cropping, yield was depressed by $10-20 \%$. Yield depression varied from year to year. There seemed to be a relationship with weather conditions. In 1984 and 1985 , the weather was colder and wetter than normal, especially in June, and yield reduction for continuous cropping was higher than in 1986, which had a relatively dry and warm summer (except for August and September).

Yield depression for rotation PM in Experiment 1 was restricted in the first three cycles, but in the fourth cycle of the rotation, yield depression was comparable to that accompanying continuous cropping.

Other authors also report yield reductions for continuous cropping of maize. Zawiślak et al. (1982) in Poland compared continuous cropping with the rotation: oats-flax-winter rye-potato-silage maize from the fifth to the eleventh year. Averaged over seven years continuous cropping yielded $19 \%$ less. Yield depression varied every year and ranged from $9 \%$ to $30 \%$. Györffy (1984) states that in a crop rotation experiment in Hungary, averaged over 1961-1982, continuous cropping of maize produced $14 \%$ less grain than the rotation barley-pea-wheat-maize. In a survey of 559 farmers' fields in Hungary, Lörincz et al. (1981) found a strongly negative linear correlation between the number of times maize had been grown on the same field and grain yield. The yield after five consecutive years of maize on the same field was $20 \%$ lower than that in fields where maize was grown 
for the first time. In France, Le Floch (1983) found a grain yield for continuous cropping that was 10-15\% lower than a two-year rotation wheat - maize. In Canada, Bolton et al. (1976) and in the USA, Williams \& Schmitthenner (1963) and Richards (1978) reported marked yield losses for continuous cropping of maize.

On the other hand, in Germany, Eberhard (1986) and in Denmark, Flengmark (1986), found no clear lower yields for continuous cropping. However, in their experiments the broad rotations with $50 \%$ or more cereals were infested with Heterodera avenae. This nematode seriously depresses the growth of maize (Küthe \& Rössner, 1978; Vez, 1975; Behringer, 1975). Therefore it may be expected that in those experiments maize probably did not produce the maximum yield in the broad rotations.

In Experiment 2, yield depression for continuous cropping was just as high in fields with a yearly application of $100 \mathrm{t}$ of cattle slurry as in fields without cattle slurry. Le Floch (1983) states that a yearly application of $50 \mathrm{t}$ of pig slurry per hectare reduces the negative effect of continuous cropping. However, in the experiment he refers to, continuously cropped fields received $50 \mathrm{t}$ of slurry per hectare each year, whereas on the wheat-maize fields, only the maize crop received $50 \mathrm{t}$ of slurry per hectare. Therefore, the ameliorating effect of pig slurry in his experiment may be attributed to the higher fertility level of continuously cropped plots.

For the first few weeks after emergence, continuously cropped maize does not differ in growth rate from rotationally cropped maize and the number of plants per $\mathrm{m}^{2}$ is the same for both cropping systems. However, in continuous cropping, plant growth lags behind, starting from 4 to 5 weeks after emergence. No specific disease symptoms are perceptible in the aerial parts of plants, but final plant height is $10-20$ $\mathrm{cm}$ less than that of rotationally cropped maize. Zawiślak et al. (1982) found a similar effect. In the present experiments, no indications were found that the maturation of a maize crop was accelerated by continuous cropping; at final harvest the dry matter content of the whole plant was not higher than that of maize in broad rotations. Under higher levels of radiation and a drier autumn than normally occurs in the Netherlands, maturation might be accelerated by continuous cropping, because plants with a deteriorated root system are more sensitive to drought.

The lower yield for continuous cropping in Experiments 1 and 2 is not caused by nematodes. This is in agreement with results reported by Scholte \& s'Jacob (1983). However, there is a strong association with root health. Root rot was most severe with continuous cropping. In Experiment 3 the observed yield differences between treatments could nearly completely be explained by differences in degree of root rot.

The relationship between the incidence of root rot and cropping frequency was very evident in Experiments 1 and 2. These findings were supported by a survey of 91 farmers' fields, carried out by Scholte \& Schröder. In New Zealand, Fowler (1980) found no clear relation between cropping frequency and the incidence of root rot. The pathogens responsible for root rot in New Zealand may differ from those in the Netherlands.

In Experiments 1 and 2, weed control was very successful and soil structure did not differ between continuous cropping and the broad rotations. The annual rate of 


\section{K. SCHOLTE}

fertilization was high, and chemical soil analysis proved that potassium and phosphorus contents were at least as high (Experiment 1) or even higher (Experiment 2) in fields continuously cropped with maize than in rotational fields.

Experiment 3 proved that the yield depression that occurs with continuous cropping, as found in Experiments 1 and 2, must be caused by a biological agent. Yield differences between continuous cropping and the broad rotations that occurred in untreated soil disappeared completely after the soil had been sterilized by gamma irradiation. Application of metalaxyl was also effective, especially in soil of Experiment 1: root rot decreased and yield increased. Metalaxyl is highly selective to fungi of the order of the Peronosporales (Kerkenaar \& Kaars Sijpesteijn, 1981), including Pythium spp. Root rot in maize may be induced by Pythium arrhenomanes and P. graminicola (Rouhani et al., 1979; Rao et al., 1978). In 1984, H. Rouhani (Laboratoire de Recherches de la Chaire de Biologie Végétales, Montpellier, France) analysed soil samples of continuously cropped fields from our Experiments 1 and 2. He found that both soils were infested with $P$. arrhenomanes: the soil from Experiment 1 severely, and the soil from Experiment 2 moderately. Pythium spp. develop best when the environment is moist. This could explain why the yield depression accompanying continuous cropping was much greater in 1984 and 1985 , when the first half of the growing season was wetter than normal, than in 1986, when that period was relatively dry.

In addition to Pythium spp., Fusarium spp. (Krüger \& Rogdaki-Papadaki, 1980) and a recently discovered fungus 'black mycelium' (Krüger \& Speakman, 1984) may cause root rot in maize. The dosage of benomyl used in Experiment 3 is effective against numerous pathogenic soil fungi, including Fusarium spp., but does not control Pythium spp. (Bollen \& Fuchs, 1970). The positive effect of benomyl on yield and root health, especially with soil of Experiment 2, indicates that also soil fungi other than Pythium cause the root system of maize to disintegrate.

Pencycuron is very specific for Rhizoctonia solani, but does not work against other soil fungi such as Pythium and Fusarium (Yamada, 1986). In Experiment 3, pencycuron did not have any positive effect on yield and root health with continuous cropping. This indicates that $R$. solani is not a cause of root rot in Experiments 1 and 2. In France, Perraton \& Lucas (1983) and in the USA, Sumner \& Bell (1982, 1986 ) proved that $R$. solani anastomosis group 2-type 2 was able to induce severe root rot in maize, attended by lower yields. From New Zealand, Fowler (1980) reports that there $R$. solani is the most important pathogen that causes root rot in maize, but no clear relationship between the cropping frequency of maize and the incidence of root rot was found.

\section{Acknowledgements}

The author is greatly indebted to L. Haalstra for his skilful technical assistance in the execution and maintenance of the experiments and to W. Bussink for collecting data in 1984 as part of his study programme at Wageningen Agricultural University.

The survey presented in Table 6 was carried out in close cooperation with $\mathrm{J}$. 
Schröder (Research Station for Arable Farming and Field Production of Vegetables, Lelystad, Netherlands).

\section{References}

Behringer, R. D.. 1975. Einfluss des Getreidezystenälchens (Heterodera avenae) auf Wachstum und Ertrag beim Mais. Gesunde Pflanzen 27: 138-140.

Bollen G. J. \& A. Fuchs, 1970. On the specificity of the in vitro and in vivo antifungal activity of benomyl. Netherlands Journal of Plant Pathology 76: 299-312.

Bolton, E. F., V. A. Dirks \& J. W. Aylesworth, 1976. Some effects of alfalfa, fertilizer and lime on corn yields in rotations on clay soil during a range of seasonal moisture conditions. Canadian Journal of Soil Science 56: 21-25.

Eberhard, D., 1986. Continuous grain-maize cropping-results of 16 years field trials in South-West-Germany. In: Continuous maize cropping. Proceedings of the European Maize Meeting (Veldhoven, Netherlands), p. 12-117. Nederlands Graancentrum, Wageningen.

Flengmark, P., 1986. Maize as monoculture or in rotation: In: Continuous maize cropping. Proceedings of the European Maize Meeting (Veldhoven, Netherlands), p. 18-20. Nederlands Graancentrum, Wageningen.

Fowler, M., 1980. Root rot-maize growers must live with it. New Zealand Journal of Agriculture 141: $45-47$.

Grisham, M. P., 1984. Cross inoculation of Rhizoctonia solani anastomosis group 2 type 2 from carrot, sugar beet, corn and St. Augustine grass, Phytopathology 74: 794.

Györffy, B., 1984. Fruchtfolge und Monokultur im Maisanbau. Tagungsbericht, Akademie der Landwirtschaftswissenschaften der DDR, Berlin 224: 119-123.

Herr, L. J. \& D. L. Roberts, 1980. Characterization of Rhizoctonia populations obtained from sugar beet fields with differing soil textures. Phytopathology 70: 476-480.

Hyakumachi M.\& T. Ui, 1982. Decline of Rhizoctonia root rot during sugar beet monoculture. Memoirs of the Faculty of Agriculture, Hokkaido University 13: 445-454.

Kerkenaar, A. \& A. Kaars Sijpesteijn, 1981. Antifungal activity of metalaxyl and furalaxyl. Pesticide Biochemistry and Physiology 15: 71-78.

Kolenbrander, G. J. 1981. Effect of injection of animal waste on ammonia losses by volatilisation on arable land and grassland. In: J. C. Brogan (Ed.), Nitrogen losses and surface run-off from landspreading of manures, p. 425-439. Martinus Nijhoff/Dr. W. Junk, The Hague/Boston/London.

Krüger, W. \& J. B. Speakman, 1984. Ein bisher unbekannter Pilz 'Schwarzes Myzel' als Ursache einer Wurzelfäule beim Mais. Zeitschrift für Pflanzenkrankheiten und Pflanzenschutz 91: 1-11.

Krüger, W. \& C. Rogdaki-Papadaki, 1980. Über die Wirkung von Temperatur, Bodenart, Bodenverdichtung und Düngung auf die Wurzelfäule und das Pilzspectrum des Maises. Zeitschrift für Pflanzenkrankheiten und Pflanzenschutz 87: 298-316.

Küthe, K. \& J. Rössner, 1978. Einsatz von Pflanzenschutzpreparaten gegen Phytonematoden zur Ertragssicherung bei Mais. Anzeiger für Schädlungskunde, Pflanzenschutz, Umweltschutz 51: 102-107.

Le Floch, D., 1983. La monoculture de maïs est-elle possible? In: Journées d'etude Rotations céréalières intensives ONIC-INRA: 1-22.

Lörincz, J., S. Sipos, Z. Menyhgert, J. Angyan \& L. Radics, 1981. Elöveteményhatás a kukoricatermesztésben. I. Az elövetemény hatása a kukoricaállományokban felhasznált mütrágya hatékonyságára és a hozamokra. Növénytermelés 30: 557-565.

Perraton B. \& P. Lucas, 1983. Rôle de Rhizoctonia solani Kühn dans la manifestion de certains symptômes de verse parasitaire du maïs. Agronomie 3: 791-796.

Rao, B., A. F. Schmitthenner, R. Caldwell \& C. W. Ellet, 1978. Prevalence and virulence of Pythium species associated with root rot of corn in poorly drained soil. Phytopathology 68: 1557-1563.

Richards, G. E., 1978. Maize-soybean rotations and continuous cropping in Northern United States. Proceedings Agronomy Society of New Zealand 8: 5-9.

Rouhani, H., P. Davet, B. Poinso, A. Beyries \& C. M. Messiaen, 1979. Inventaire et évaluation du pouvoir pathogène des composants de la microflore fongique sur racine de maïs en France. Annales de Phytopathologie 11: 69-93. 


\section{K. SCHOLTE}

Scholte, K. \& J. J. s'Jacob, 1983. The influence of continuous cropping and free-living root lesion nematodes on yield of fodder maize. Netherlands Journal of Plant Pathology 89: 127-139.

Schröder, J., 1986. Consequences of continuous cropping of maize. In: Continuous maize cropping. Proceedings of the European Maize Meeting, (Veldhoven, Netherlands), p. 29-42. Nederlands Graancentrum, Wageningen.

Sumner, D. R. \& D. K. Bell, 1982. Root diseases induced in corn by Rhizoctonia solani and Rhizoctonia zeae. Phytopathology 72: 86-91.

Sumner, D. R. \& D. K. Bell, 1986. Influence of crop rotation on severity of crown and brace root rot caused in corn by Rhizoctonia solani. Phytopathology 76: 248-252.

Vez, A., 1975. Le maïs dans la rotation. Revue Suisse d'Agriculture 7: 63-66.

Williams, L. E. \& A. F. Schmitthenner, 1963. Effect of crop rotation on yields, stalk rot, and root rot of corn. Phytopathology 53: 1412-1414.

Yamada, Y., 1986. Monceren (pencycuron), a new fungicide. Japan Pesticide Information No 48: 16-22.

Zawiślak, K., W. Niewiadomski \& E. J. Rzeszutek, 1982. Tolerancja kukurydza na wieloletni siew po sobie. Acta Universitatis Agriculturae Brno, Facultas Agronomica 3: 95-101. 